\title{
SWEET BASIL (Ocimum basilicum L.) FLOWERING AFFECTED BY FOLIAR NITROGEN APPLICATION
}

\author{
Renata Nurzyńska-Wierdak \\ Department of Vegetable Growing and Medicinal Plants, \\ University of Life Sciences in Lublin, Leszczyńskiego 58, 20-068 Lublin, Poland \\ e-mail: renata.nurzynska@up.lublin.pl
}

Received: 20.11.2010

\begin{abstract}
The aromatic and curative properties of basil are connected with the presence of essential oil, mainly in the leaves and flowers. Herb yield and the quality of basil oil are related to the effect of genetic, ontogenetic and environmental factors. In the studies conducted in the years 2008-2009, the effect of basil cultivar and foliar feeding upon selected flowering features was examined. In an unheated plastic tunnel, plants of Kasia, Wala, Genua Star and Opal cultivars were grown. Foliar feeding was done by the application of $0.5 \%$ urea solution or by spraying the plants with water. During harvest the characteristic features of flowering were determined, i.e. the number and length of inflorescences, as well as the number of verticils and flowers per inflorescence. A vast differentiation was demonstrated in flowering of sweet basil plants of the examined cultivars. The most inflorescences were formed by the plants of the Polish cultivar Kasia, compared to the remaining ones. The longest inflorescences with the highest number of flowers in the main inflorescence were found in 'Genua Star'. Foliar feeding of the plants with nitrogen caused a significant increase of inflorescence number, but it did not significantly affect the remaining features of basil flowering.
\end{abstract}

Key words: Ocimum basilicum L., cultivars, foliar feeding, urea, flowers, unheated plastic tunnel

\section{INTRODUCTION}

Sweet basil (Ocimum basilicum L.) is one of the most important species of the Ocimum genus, being a source of essential oil. This species comes from the tropical climate and has strict requirements concerning heat and light. Basil is an annual aromatic plant of decorative habit, leaves and flowers. It is also a highly valued melliferous plant. The visiting and pollinating insects are mainly honeybees and solitary bees, as well as bumblebees (B o ż e k, 2000; M a l e r b o - S o u z a et al. 2000; Chwil, 2007). Flowers of basil seem to be a good source of nectar for the honeybee because of high yield of sugars and long flowering period (Chwil , 2003; 2007). Basil flowering starts in June and lasts up to September. The flowers are of different colours: from white in green-leaved cultivars, to pinkviolet in purple-leaved cultivars. They grow in pseudo-verticils, forming peak pseudo-ears. As $\mathrm{Chwil}$ (2003) reports, a basil flower lives on average from two to three days, reaching the length of $1.25 \mathrm{~cm}$. Buds open during the whole day, with greater intensity during the hours before noon.

Within the Ocimum genus there exist many forms, botanic varieties and hybrids differing in morphological and developmental features, which results from the easiness of crossing and genetic polymorphism. Depending on the geographical region, various basil cultivars are grown and used as medicinal, seasoning or oil plants. Essential oil, obtained from basil herb through distillation of leaves and blooming peaks of sprouts, is applied in the perfume, food and pharmaceutical industries. This substance, with a rich, specific and pleasant aroma, has insecticidal, fungistatic and antibacterial effect ( $\mathrm{Makri}$ and $\mathrm{Kintzios}$, 2007; D a mbolena et al. 2010, Run y oro et al. 2010). Climatic conditions during basil cultivation substantially affect the growth, flowering and chemical composition of plants (Purkayastha and Nath，2006; Nurzyńska-Wierdak，2007a,b; Shat ar etal. 2007; Fenech-Larios et al. 2008). Noguchi and Ichimura (2004) demonstrated that the number of leaves, fresh plant weight and concentration of basil essential oil increased under the influence of growing in high temperatures $\left(30 / 25^{\circ} \mathrm{C}\right)$. The 
authors give this range of temperature and the 12-hour day as the optimal conditions for producing fresh basil herb. Besides, C h a ng et al. (2008) proved a distinct influence of solar radiation upon basil growth, as well as on quantity and quality of essential oil. The authors report that basil growth takes its best course under full insolation; however, plants tolerate slight shading.

Another group of factors affecting growth and development of basil are agrotechnical factors, such as cultivation method, harvest term, fertilization, or irrigation (Tansi and Nacar, 2000; Nurzyńska-Wierdak, 2002; Nguyen and Niemeyer, 2008; Zheljazkov et al. 2008; B i esiada and Kuś, 2010; Dzida, 2010a,b; Nurzyńska-Wierdak, 2011a,b). Basil responds very well to mineral fertilization and can take full advantage of nutrients $(\mathrm{Nguyen}$ and $\mathrm{Niemeyer}$ 2008, Z heljazkov et al. 2008, B iesiada and Kuś 2010). On the other hand, however, Tesi et al. (1995) demonstrated high sensitivity of basil plants of 'Genovese' cultivar upon a high concentration of nutrients in the substratum. In the cultivation of this plant, a recommended procedure is foliar feeding, which favourably affects both herb yield and its quality (D zida 2010a, b, N u rzyńska-Wierdak, 2011a, b). The undertaken studies were aimed at demonstrating the relationship between basil cultivar and nitrogen application in the form of urea and flowering of plants cultivated in an unheated plastic tunnel.

\section{MATERIAL AND METHODS}

The experiment was conducted in the Experimental Farm of the University of Life Sciences in Lublin in the period from March to June 2008 and 2009. Four sweet basil cultivars were grown: Kasia, Wala (cultivars with light violet flowers), 'Genua Star' (a cultivar with white flowers), and Opal (a cultivar with purple flowers) (Table 1). The check basil cultivars represented typical essential oil composition and biomass productivity of basil chemotypes grown in Europe. Sowing material came from the Institute of Natural Fibers and Herbal Plants in Poznań (Polish cultivars: Kasia, Wala) and from PNOS-Ożarów Mazowiecki (the remaining cultivars). The experiment was established using the complete randomization method in four replications, as a two-factor experiment. Factor A was the basil cultivar (four cultivars), factor B was feeding plants with nitrogen (fed and unfed plants).

Basil was grown from seedlings produced in a heated glasshouse; seeds were sown in the third decade of March 2008 and 2009, into sowing boxes filled with peat substrate. Before sowing, the seeds had been dressed with a preparation with fungicidal activity Dithane Neo Tec 75WG. 6-7 cm high seedlings were thinned into multiplates filled with peat substrate. Af- ter hardening, $15-16 \mathrm{~cm}$ high seedlings were planted in an unheated plastic tunnel at the end of April. The soil at the experimental site was lessive, derived from medium silty loam with $1.9 \%$ organic matter, $\mathrm{pH}_{\mathrm{H} 2 \mathrm{O}} 7.4$, EC $0.31 \mathrm{mS} \times \mathrm{cm}^{-1}$, and the concentration of available nutrients in $\mathrm{mg} \times \mathrm{dm}^{-3}$ as follows: $8.0 \mathrm{~N}-\mathrm{NH}_{4}+\mathrm{N}^{-\mathrm{NO}_{3}}$, $60 \mathrm{P}, 20 \mathrm{~K}$ and $60 \mathrm{Mg}$. Cultivator tillage was performed after previous spreading of a compound fertilizer Azofoska at the rate of $45 \mathrm{~kg} \cdot 100 \mathrm{~m}^{-2}$, contributing to the soil: $306 \mathrm{mg} \mathrm{N}-\mathrm{NH}_{4}+\mathrm{N}-\mathrm{NO}_{3}, 65 \mathrm{mg}$ P, $360 \mathrm{mg} \mathrm{K}$, and $60 \mathrm{mg} \mathrm{Mg} \cdot \mathrm{dm}^{-3}$. The plants were grown at a spacing of $30 \times 30 \mathrm{~cm}$; there were 36 plants on one plot. The surface area of the whole experimental field was $90 \mathrm{~m}^{2}$, and of one plot $-4.2 \mathrm{~m}^{2}$. During the time of the experiment, the thermal conditions were generally favorable for basil development. The temperature distributions in particular decades of April, May and June were similar, although certain differences were found in April 2009. Generally, the temperature increased starting from the $1^{\text {st }}, 2^{\text {nd }}$ until the $3^{\text {rd }}$ decade of each month; besides, mean monthly air temperatures in the months under discussion were close to the long-term mean. Air temperature in April and May 2008 was slightly lower than in the year 2009.

During the growing period, manual weeding of the plants was performed several times, as well as continuous irrigation was provided by means of dripping lines. Foliar feeding of basil was performed with the use of a hand sprayer, applying the $0.5 \%$ urea solution until complete wetting of the leaf blade surface. The plants that were not fed with nitrogen at that time were wetted with water in the same way. Nitrogen application and wetting the plants with water were performed four times, in 10-day intervals, starting from the third decade of May when the plants were at the first stage of extensive vegetative growth, and finishing two weeks before herb harvest - about mid-June. During the growing season, no pests or diseases were observed on the basil plants, but many visiting and pollinating insects, like honeybees and bumblebees. The herb was harvested manually, cutting the whole above-ground part of the plant, at a height of $10-15 \mathrm{~cm}$ above the soil surface, when the plants were in the initial period of full bloom. For 'Kasia' and 'Wala' cultivars, the harvest fell at the end of June, and for the remaining ones - at the first decade of July, which was related to different plant development intensity in the examined cultivars.

During harvest, characteristic features of plant flowering were determined, i.e. the number and length of inflorescences, as well as the number of verticils and number of flowers per inflorescence. The measurements were performed on 24 plants (6 plants from each replication). The obtained results were statistically elaborated using the method of variance analysis for double classification at the significance level of $\alpha=0.05$. 


\section{RESULTS}

A significant effect of cultivar and nitrogen feeding on the number of basil inflorescences was demonstrated (Table 2). The mean number of basil inflorescences was 30.6 pcs ' plant $^{-1}$. The 'Kasia'cultivar was distinguished by the significantly greatest number of inflorescences (40.1 pcs $\times$ plant $^{-1}$ ) (Fig. 1), while the plants of 'Genua Star' produced the least number of inflorescences (16.6pcs $\cdot$ plant $\left.^{-1}\right)$. The cultivars Wala and Opal were characterized by a similar number of inflorescences per plant. The application of urea significantly differentiated the flowering traits in basil. The plants fed with nitrogen produced more inflorescences $\left(35.3 \mathrm{pcs} \times \mathrm{plant}^{-1}\right)$ compared to the non-fertilized plants $\left(26.0\right.$ pcs plant $\left.^{-1}\right)$. The significance of correlation between the examined factors was also demonstrated for the number of basil inflorescences. The climatic conditions during vegetation distinctly modified basil flowering. The plants of the studied basil cultivars grown in 2008, except for Wala, were distinguished by a greater number of inflorescences than the plants grown in 2009.

The mean length of basil inflorescences was $23.4 \mathrm{~cm}$ and it was significantly differentiated in the examined cultivars (Table 2). The plants of 'Genua Star', which produced the least number of inflorescences, were distinguished by the longest inflorescences $(24.2 \mathrm{~cm})$. The shortest inflorescences $(22.9 \mathrm{~cm})$ were found in the plants of 'Opal' (Fig. 2). The cultivars Kasia and Wala were characterized by similar inflorescence lengths. No significant effect of nitrogen application

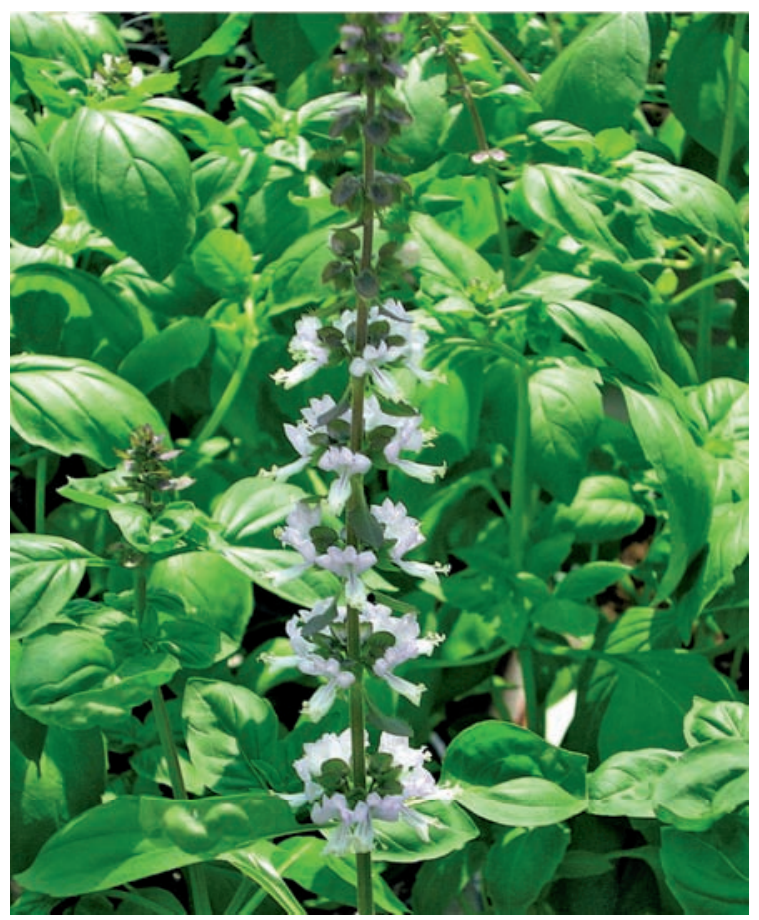

Fig. 1 Inflorescence in 'Kasia' basil on the flowering trait in question was found; nevertheless, longer inflorescences were formed by the plants fed with nitrogen, compared to the remaining ones.

The number of verticils in the main inflorescence was significantly affected by the investigated factors and it averaged 10.4 (Table 2). The basil plants of 'Wala' and 'Genua Star' produced more verticils in the main inflorescence than the plants of 'Kasia' and 'Opal'. The applied procedure of urea application did not significantly affect the feature under discussion. Neither was a significant correlation between the investigated factors and the examined feature of basil flowering demonstrated.

Flowering of basil in the study years under discussion was abundant, which resulted from a large number of inflorescences and a large number of flowers per inflorescence. The mean number of flowers in the main inflorescence was 59.4 (Table 3). The largest number of flowers in the main inflorescence (61.9) was produced by the plants of 'Genua Star' (Fig. 3), and they were also distinguished by the greatest inflorescence length (Table 2). The significantly lowest number of flowers per inflorescence (55.5) was in the plants of 'Opal', and their inflorescences were also the shortest (Table 2). The number of flowers in the inflorescences of the 'Kasia' and 'Wala' plants was on average the same (Figs 1, 4). The inflorescences of these cultivars were also characterized by similar length. Urea application was found to have no significant effect on the number of basil flowers, as well as no significant correlation was found between the examined factors and the feature under discussion.

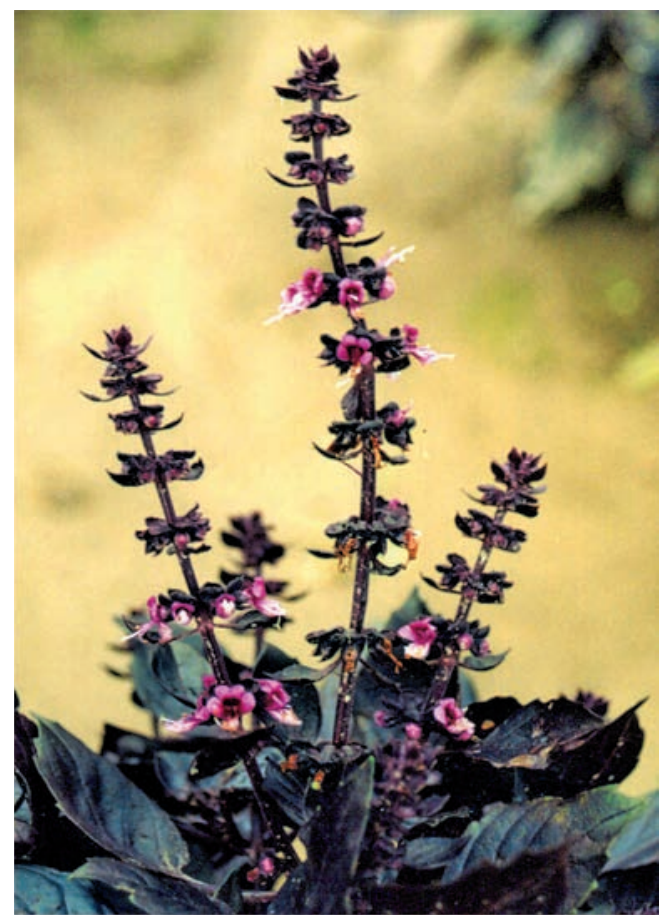

Fig. 2 Inflorescence in 'Opal' basil 


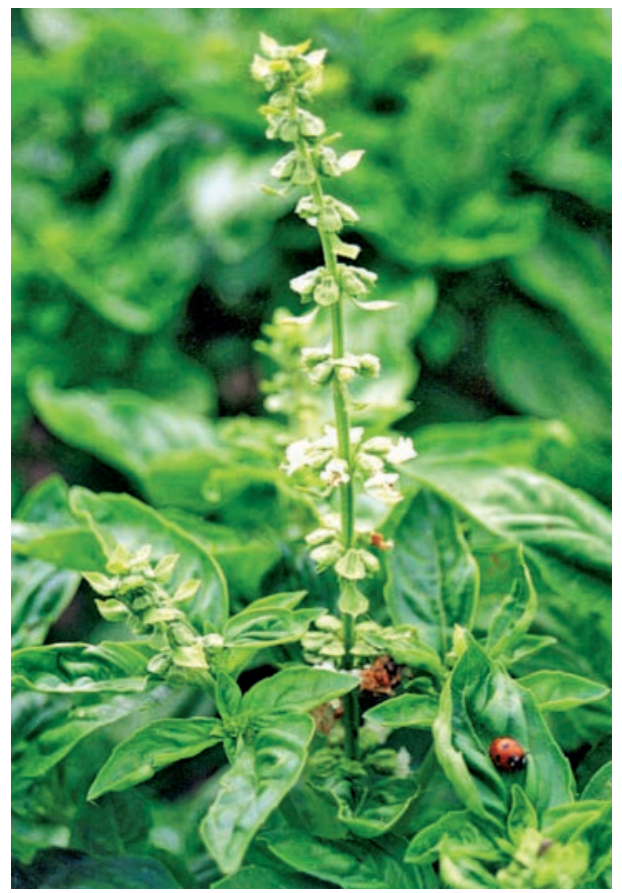

Fig. 3 Inflorescence in 'Genua Star' basil

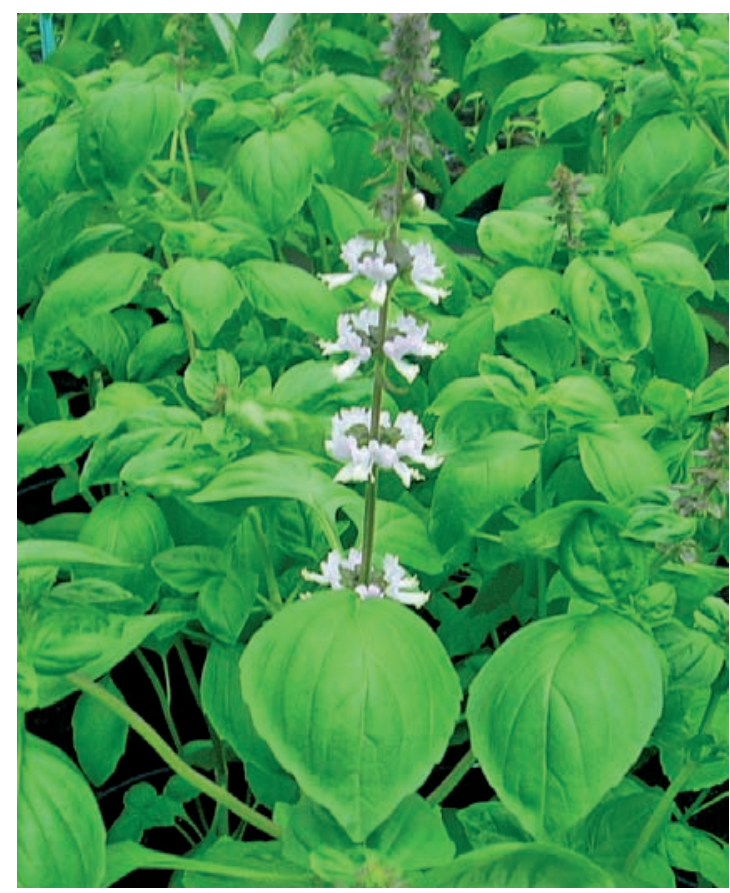

Fig. 4 Inflorescence in 'Wala' basil

Table 1.

Morphological features of studied basil cultivars

\begin{tabular}{cccccc}
\hline Basil cultivar & Plant habit & Height & Leaf colour & Type of inflorescence & Flower colour \\
\hline Kasia & rounded & medium-sized & green & verticellaster & light-violet \\
Wala & uplifted & tall & green & verticellaster & light-violet \\
Genua Star & uplifted & medium-sized & green & verticellaster & white or purplish white \\
Opal & uplifted & short & purple & verticellaster & purple \\
\hline
\end{tabular}

Table 2.

Effect of cultivar and foliar feeding with nitrogen on number and length of inflorescences

\begin{tabular}{|c|c|c|c|c|c|c|c|}
\hline \multirow{2}{*}{ Basil cultivar } & \multirow{2}{*}{$\begin{array}{l}\text { Supplemental } \\
\text { fertilization } \\
\text { with nitrogen }\end{array}$} & \multicolumn{3}{|c|}{$\begin{array}{l}\text { Number of inflorescences } \\
\text { (per plant) }\end{array}$} & \multicolumn{3}{|c|}{$\begin{array}{l}\text { Inflorescence length } \\
(\mathrm{cm})\end{array}$} \\
\hline & & 2008 & 2009 & mean & 2008 & 2009 & mean \\
\hline Kasia & \multirow{5}{*}{$\begin{array}{l}\text { Foliar feeding } \\
\text { with nitrogen }\end{array}$} & 71.4 & 32.4 & 51.9 & 26.0 & 22.5 & 24.3 \\
\hline Wala & & 25.4 & 38.3 & 31.9 & 27.7 & 21.7 & 24.7 \\
\hline Genua Star & & 24.4 & 14.5 & 19.5 & 29.1 & 22.0 & 25.6 \\
\hline Opal & & 55.3 & 20.3 & 37.8 & 25.0 & 22.7 & 23.9 \\
\hline mean & & 44.1 & 26.4 & 35.3 & 27.0 & 22.3 & 24.7 \\
\hline Kasia & \multirow{5}{*}{$\begin{array}{l}\text { Without foliar } \\
\text { feeding } \\
\text { with nitrogen }\end{array}$} & 33.3 & 23.2 & 28.3 & 23.0 & 20.4 & 21.7 \\
\hline Wala & & 18.6 & 46.0 & 32.3 & 24.0 & 20.8 & 22.4 \\
\hline \multirow{2}{*}{$\begin{array}{l}\text { Genua Star } \\
\text { Opal }\end{array}$} & & 15.2 & 12.2 & 13.7 & 24.0 & 25.3 & 24.7 \\
\hline & & 39.0 & 20.2 & 29.6 & 22.2 & 21.3 & 21.8 \\
\hline mean & & 26.5 & 25.4 & 26.0 & 23.3 & 21.9 & 22.6 \\
\hline Kasia & & 52.4 & 27.8 & 40.1 & 24.1 & 21.5 & 22.8 \\
\hline Wala & & 22.0 & 42.2 & 32.1 & 26.0 & 21.2 & 23.6 \\
\hline Genua Star & & 19.8 & 20.2 & 20.0 & 26.4 & 22.0 & 24.2 \\
\hline Opal & & 47.2 & 13.4 & 30.3 & 24.3 & 23.7 & 24.0 \\
\hline \multicolumn{8}{|l|}{$\mathrm{LSD}_{005}$} \\
\hline \multirow{2}{*}{\multicolumn{2}{|c|}{$\begin{array}{l}\text { cultivar } \\
\text { foliar feeding } \\
\text { cultivar } \times \text { foliar feeding }\end{array}$}} & 4.6 & n. s. & & 1.2 & n. s. & \\
\hline & & 14.2 & 11.0 & & n. s. & n. s. & \\
\hline
\end{tabular}


Table 3.

Effect of cultivar and foliar feeding with nitrogen on number of verticils and flowers in the main inflorescence

\begin{tabular}{|c|c|c|c|c|c|c|c|}
\hline \multirow{2}{*}{ Basil cultivar } & \multirow{2}{*}{$\begin{array}{c}\text { Supplemental } \\
\text { fertilization } \\
\text { with nitrogen }\end{array}$} & \multicolumn{3}{|c|}{ Number of verticils } & \multicolumn{3}{|c|}{ Number of flowers } \\
\hline & & 2008 & 2009 & mean & 2008 & 2009 & mean \\
\hline Kasia & \multirow{5}{*}{$\begin{array}{l}\text { Foliar feeding } \\
\text { with nitrogen }\end{array}$} & 10.1 & 9.8 & 10.0 & 62.0 & 59.1 & 60.6 \\
\hline Wala & & 12.2 & 10.2 & 11.2 & 58.4 & 61.5 & 60.0 \\
\hline Genua Star & & 10.8 & 11.3 & 11.1 & 56.4 & 68.0 & 62.2 \\
\hline Opal & & 9.2 & 8.5 & 8.9 & 60.0 & 51.5 & 55.8 \\
\hline mean & & 10.6 & 10.0 & 10.3 & 59.2 & 60.0 & 59.6 \\
\hline Kasia & \multirow{5}{*}{$\begin{array}{l}\text { Without foliar } \\
\text { feeding } \\
\text { with nitrogen }\end{array}$} & 9.9 & 9.7 & 9.8 & 60.0 & 59.0 & 59.5 \\
\hline Wala & & 11.9 & 10.5 & 11.2 & 56.7 & 63.5 & 60.1 \\
\hline Genua Star & & 11.6 & 10.7 & 11.2 & 58.7 & 64.5 & 61.6 \\
\hline Opal & & 10.0 & 8.9 & 9.5 & 56.8 & 53.5 & 55.2 \\
\hline mean & & 10.9 & 10.0 & 10.5 & 58.1 & 60.1 & 59.1 \\
\hline Kasia & & 10.0 & 9.7 & 9.9 & 61.0 & 59.0 & 60.0 \\
\hline Wala & & 12.1 & 10.4 & 11.3 & 57.6 & 62.5 & 60.1 \\
\hline Genua Star & & 10.4 & 11.0 & 10.7 & 57.6 & 66.2 & 61.9 \\
\hline Opal & & 9.6 & 8.7 & 9.2 & 58.4 & 52.5 & 55.5 \\
\hline \multirow{3}{*}{\multicolumn{2}{|c|}{$\begin{array}{l}\mathrm{LSD}_{0.05} \\
\text { cultivar } \\
\text { foliar feeding } \\
\text { cultivar } \times \text { foliar feeding }\end{array}$}} & 1.7 & 1.1 & & 3.3 & 6.7 & \\
\hline & & n. s. & n. s. & & n. s. & n. s. & \\
\hline & & n. s. & n. s. & & & & \\
\hline
\end{tabular}

\section{DISCUSSION}

Morphological differentiation, including that of Ocimum basilicum L. flowering, creates possibilities for growing new cultivars for decorative, aromatic, or pharmaceutical purposes ( $\mathrm{Tansi}$ and $\mathrm{Nacar}$, 2000; Makri and Kintzios, 2008; B ączekKwinta et al. 2009; Dambolena et al. 2010). The studied basil cultivars were characterized by significant differentiation in the analyzed flowering traits, such as the number and length of inflorescences, as well as the number of verticils and flowers in the main inflorescence. The highest number of inflorescences (40.1) was in 'Kasia', whereas the most flowers per inflorescence (61.9) were found in 'Genua Star'. N a $\mathrm{z}$ i $\mathrm{m}$ et al. (2009) report that basil produces from $15 \pm 3$ to $22 \pm 4$ inflorescences and from $92 \pm 18$ to $134 \pm 22$ flowers in total, but the differences between cultivars are statistically insignificant. Considering the abundance of essential oils in basil flowers, sometimes exceeding the amount of this substance in leaves ( $\mathrm{Tansi}$ and $\mathrm{N}$ a c a r, 2000), the examined cultivars, producing much more inflorescences and flowers in total, can be regarded as very valuable. The relative stability of the analyzed flowering traits in both study years is also noticeable, which, in turn, may result from a certain stability of climatic conditions of the crop grown in the plastic tunnel.

Basil, as a plant with relatively strict nutritional requirements, responds well to mineral and organic fertilizations (A rabaci and B ayra m, 2004; S ifola and Barbieri, 2006; Biesiada and Kuś, 2010; D zida 2010a, b; N u r z y ńska-W ierdak, 2011a, b). The increased growth and yield as an effect of nutrients, found in the previous papers ( $\mathrm{Nu} \mathrm{r} \mathrm{z} \mathrm{y} \mathrm{ń} \mathrm{-}$ s k a - W i e rdak, 2011a, b), is not related, however, to the modification of basil flowering as an effect of feeding it with nitrogen. The application of urea significantly increased only the number of inflorescences in the examined basil plants, but it did not affect their length and number of flowers, as well as verticils. The flowering process seems to be relatively independent of agrotechnical factors, and the main part in its modification is played by the genetic, ontogenetic and climatic factors. The increased number of inflorescences as an effect of urea application can be explained by the increase of height, diameter and number of branches, on whose ends inflorescences are formed ( $\mathrm{Nu} \mathrm{r} \mathrm{z} \mathrm{y} \mathrm{ń} \mathrm{-}$ ska-Wierdak, 2011b).

During comparison of the plants of the studied cultivars, certain interdependencies were found within the groups with green leaves and white flowers, as well as within those with purple leaves and light-violet flowers. The 'Genua Star' cultivar, included in the first of the above-mentioned groups, had the lowest quantity of the longest inflorescences with the highest number of flowers in the main inflorescence, which is confirmed by the studies by $\mathrm{Nazim}$ et al. (2009). In the previous studies (N u r z y ń s k a - W i e r d a k, 2002), in turn, a reverse relationship was demonstrated: basil 
plants of a green-leaved cultivar with white flowers had a significantly higher number of inflorescences than plants forming purple leaves and light violet flowers. However, the inflorescence length was greater in the green-leaved cultivar. This phenomenon can be explained by the flowering features under discussion being more or less susceptible to growing conditions demonstrated in the presented study. The number of inflorescences seems to be the least stable of the discussed flowering features. At the same time, it is the most dependent upon plant foliar feeding. Similarly, in other basil cultivars ( $\mathrm{Nurzy}$ ń $\mathrm{ka}-\mathrm{W}$ ierdak, $2007 \mathrm{a}, \mathrm{b}$ ) this feature was the most variable one in the study years and in the analyzed cultivars. Differentiation in basil flowering in green and purple-leaved cultivars was demonstrated by $\mathrm{Chw}$ il (2007). The author found higher nectar weight per 10 flowers, sugar concentration in the nectar and sugar weight per 10 flowers in the green-leaved cultivar, compared to the purple-leaved cultivar. She also demonstrated a different characterization of pollen grains in the examined cultivars. Mačukanović-Jocić et al. (2007), in turn, demonstrated the structural difference between sweet basil nectaries relative to other plants from the Lamiaceae family. These results can explain different degrees of attractiveness of basil flowers for pollinating and visiting insects. They show the substantial importance of Ocimum basilicum L. as a decorative and melliferous plant.

\section{CONCLUSIONS}

1. High differentiation was demonstrated in flowering of sweet basil plants of the examined cultivars. The highest number of inflorescences was produced by the plants of the Polish cultivar Kasia compared to the remaining ones.

2. The longest inflorescences with the highest number of flowers in the main inflorescence were found in 'Genua Star'.

3. Foliar feeding of plants with nitrogen caused a significant increase of inflorescence number; however, it had no significant effect upon the remaining features of basil flowering.

4. Variability of basil morphological features related to flowering was more affected by genetic and ontogenetic factors than by climatic and agrotechnical ones.

\section{REFERENCES}

Arabaci O., Bayram E. 2004. The effect of nitrogen fertilization and different plant densities on some agronomic and technologic characteristic of Ocimum basilicum L. (Basil). J Agron. 3, (4): 255-262.
Bączek-Kwinta R., Serek B., Wątor A., Hura K. 2009. Porównanie aktywności antyoksydacyjnej odmian bazylii mierzonej różnymi metodami. / A comparison of antioxidant activity of basil cultivars assayed by different methods. Zesz. Prob. Post. Nauk Rol. 539: 45-56 (in Polish).

Biesiada A., Kuś A. 2010. The effect of nitrogen fertilization and irrigation on yielding and nutritional status of sweet basil (Ocimum basilicum L). Acta Sci. Pol. Hortorum Cultus, 9, (2): 3-12.

B ożek M. 2003. Oblot przez pszczołę miodną wybranych gatunków roślin z rodziny wargowych (f. Lamiaceae). / Honeybees foraging on some plant species from the Lamiaceae family. Ann. UMCS Lublin, sect. EEE, XII: 67-74 (in Polish).

Chang X., Anderson P.G., Wright C.J. 2008. Solar irradiance level alters the growth of basil (Ocimum basilicum $\mathrm{L}$ ) and its content of volatile oils. Environ. Exp. Bot., 63: 216-223.

Chwil M. 2003. Biologia kwitnienia i nektarowania Ocimum basilicum L. / The biology of flowering and nectar secretion of Ocimum basilicum L. Ann. UMCS Lublin, sect. EEE, XIII: 117-122 (in Polish).

Chwil M. 2007. Flowering pattern, the structure of nectary surface and nectar secretion in two varieties of Ocimum basilicum L. Acta Agrobot. 60 (1): 55-65.

Dambolena J.S., Zunino M.P., López A.G., Rubinstein H.R., Zygadlo J.A., Mwangi J.W., Thoithi G.N., Kibwage I.O., Mwalukumbi J.M., Kariuki S.T. 2010. Essentials oils composition of Ocimum basilicum L. and Ocimum gratissimum L. from Kenya and their inhibitory effects on growth and fumonisin production by Fusarium verticillioides. Innovative Food Science and Emerging Technologies, 11: 410-414.

D zida K. 2010a. Nutrients contents in sweet basil (Ocimum basilicum L.) herb depending on calcium carbonate dose and cultivar. Acta Sci. Pol. Hortorum Cultus, 9 (4):143- 151.

D zida K. 2010b. Biological value and essentials oil content in sweet basil (Ocimum basilicum L.). Acta Sci. Pol. Hortorum Cultus, 9 (4): 153-161.

Fenech-Larios L., RuIz-Espinoza F.H., Garcia-Hernández J.L., Murillo-Amador B., González-Ocampo H.A., Beltrán-Morales F.A., Fraga-Palomino H. 2008. Analysis of agronomic variables of Ocimum basilicum $\mathrm{L}$. under alternative tillage systems and standard organic practices. Tropic. Subtropic. Agroecosys. 8: 157-163.

Mačukanović-Jocić M.P., Rančić D.V., Dajić Stevanović Z.P. 2007. Florar nectaries of basil (Ocimum basilicum L): Morphology, anatomy and possible mode of secretion. South Afric. J Bot., 73: 636641.

Makri O., Kintzios S. 2007. Ocimum sp. (basil): botany, cultivation, pharmaceutical properties and biotechnology. J Herbs Spices Med. Plants, 13 (3): 123-150. 
Malerbo-Souza D.T., Mota M.O.S., NogueiraCouto R.H., Souza J.C. 2000. Insects associated to the inflorescences of basil (Ocimum basilicum L.). Rev. Brasil. Plant Med. 2 (2): 27-30.

Nazim K., Ahmed M., Uzair M. 2009. Growth potential of two species of basil in sandy soil of Karachi. Pak. J Bot., 41, 4: 1637-1644.

Nguyen P.M., NIemeyer E.D. 2008. Effects of nitrogen fertilization on the phenolic composition and antioxidant properties of basil (Ocimum basilicum L.). J Agric. Chem. 56 (18): 8685-91.

Noguchi A., Ichimura M. 2004. Effects of environmental factors on growth, flowering and essentials oil concentration and composition in sweet basil and spearmint. Hort. Res. (Japan), 3 (1): 67-70.

Nurzyńska-Wierdak R. 2002. Evaluation of growth and yield of two forms of sweet basil grown from seeds and transplants. Folia Hort. 14/2: 169-175.

Nurzyńska-Wierdak R. 2007a. Evaluation of morphological and developmental variability and essentials oil composition of selected basil cultivars. Herba Pol. 53, (3): 255-261.

Nurzyńska-Wierdak R. 2007b. Comparing the growth and flowering of selected basil (Ocimum basilicum L.) varieties. Acta Agrobot. 60 (2): 127-131.

Nurzyńska-Wierdak R. 2011a. Basil herb yield and chemical composition depending on cultivar and foliar fertilization with nitrogen. Acta Sci. Pol. Hortorum Cultus, 10 (1): 207-219.

Nurzyńska-Wierdak R. 2011b. Dynamics of growth of sweet basil (Ocimum basilicum L.) in dependence on the foliar fertilization with nitrogen. Acta Sci. Pol. Hortorum Cultus, 10 (2) (in press).

Purkayastha J., Nath S.C. 2006. Composition of the camphor-rich essential oil of Ocimum basilicum L native to Northeast India. J Essent. Oil Res., 18: 332-334.

Runyoro D., Ngassapa O., Vagionas K., Aligiannis N., Graikou K., Chinou I. 2010. Chemical composition and antimicrobial activity of the essential oils form four Ocimum species growing in Tanzania. Food Chem. 119: 311-316.

Shatar S., Altantsetseg Sh., Sarnai I., Zoljargal D., Thang T.D., Dung N.X. 2007. Chemical composition of the essential oil of Ocimum basilicum cultivated in Mongolian Desert-Gobi. Chem. Natural Comp. 43 (6): 726-727.
Sifola M.I., Barbieri G. 2006. Growth, yield and essentials oil content of three cultivars of basil grown under different levels of nitrogen in the field. Sci. Hort. 108: 408-413.

Tansi S., Nacar S. 2000. First cultivation trials of lemon basil (Ocimum basilicum var. citriodorum) in Turkey. Pak. J Biol. Sci. 3 (3): 395-397.

Tesi R., Chisci G., Nencini A., Tallarico R. 1995. Growth response to fertilization of sweet basil (Ocimum basilicum L.). International Symposium on Medicinal and Aromatic Plants, Acta Hort. 390: 93-96.

Zheljazkov V.I., Cantrell C.L., Ebelhar M.W., Rowe D.E., Coker C. 2008. Productivity, oil content and oil composition of sweet basil as a function of nitrogen and sulphur fertilization. HortScience, 43 (5): 1415-1422.

\section{Kwitnienie bazylii pospolitej pod wpływem dolistnego stosowania azotu}

\section{Streszczenie}

Właściwości aromatyczne oraz lecznicze bazylii związane są z obecnością, głównie w liściach i kwiatach, olejku eterycznego. Plon ziela oraz jakość olejku bazylii związane są z wpływem czynników genetycznych, ontogenetycznych i środowiskowych. W latach 2008-2009 badano wpływ odmiany bazylii oraz dolistnego dokarmiania roślin azotem na wybrane cechy kwitnienia. W nieogrzewanym tunelu foliowym uprawiano rośliny odmian Kasia, Wala, Genua Star i Opal. Dokarmianie dolistne prowadzono stosując $0,5 \%$ roztwór mocznika, pozostałe rośliny opryskiwano wodą. W czasie zbioru określono charakterystyczne cechy kwitnienia roślin, tj. liczbę i długość kwiatostanów oraz liczbę okółków i liczbę kwiatów w kwiatostanie. Wykazano duże zróżnicowanie w obrębie kwitnienia roślin bazylii pospolitej badanych odmian. Najwięcej kwiatostanów tworzyły rośliny polskiej odmiany Kasia w porównaniu z pozostałymi. Najdłuższe kwiatostany z największą liczbą kwiatów w kwiatostanie głównym stwierdzono u odmiany Genua Star. Dokarmianie roślin azotem powodowało istotne zwiększenie liczby kwiatostanów, natomiast nie miało istotnego wpływu na pozostałe cechy kwitnienia bazylii. 